\title{
TŁUMACZ JAKO AGENT NIE-CZYTANIA ${ }^{1}$
}

\author{
Marta Bucholc \\ Uniwersytet Warszawski
}

Przekłady mają we współczesnej nauce status co najmniej wątpliwy. Wynika to z kilku przyczyn. Po pierwsze - ze statusu tłumaczeń jako dzieł pochodnych, po drugie - z trudności, które rodzi ocena ich jakości, po trzecie - z coraz częstszego podawania w wątpliwość samej potrzeby tłumaczenia tekstów naukowych.

Zacznijmy od przyczyny pierwszej. W dobie pogoni za oryginalnością, która w piśmiennictwie naukowym jest tyleż potrzebą serca, co prawnym wymogiem i warunkiem finansowania badań, niejakie zdziwienie budzi fakt, że jakikolwiek naukowiec zabiera się do tworzenia tekstu jawnie nieoryginalnego w tym prostym sensie, że jego prawdziwym autorem jest kto inny. Nazwisko autora oryginału widnieje wszak na okładce, w bibliografiach i w opisach katalogowych, nazwisko tłumacza wprawdzie powinno się pojawiać, ale nie zawsze tak się dzieje - a jeśli zaś nawet, to kto by je zauważał. Tłumaczenie to strata czasu i energii, którą - mógłby pomyśleć ktoś nieżyczliwy - ponosić są gotowi wyłącznie ci, którzy żadnego utworu oryginalnego nie są w stanie wyprodukować. Oczywiście, znajdą się także i tacy naukowcy, dla których tłumaczenie jest po prostu sposobem zarobkowania, ten wzgląd jednak pomijam, nauka bowiem w ogólności jest wbrew przesadnym konstatacjom malkontentów - między innymi także sposobem zarobkowania.

Rzecz jasna, tłumacze dzieł naukowych niebędący naukowcami są w innej sytuacji. Oni także mogliby tworzyć dzieła pierwotne zamiast pochodnych, ale nie byłyby to zapewne dzieła naukowe. $Z$ tego wynika problem z ustaleniem standardu oceny jakości tłumaczenia. Nie wnikając w szczegółowe problemy kryteriów poprawności przekładu naukowego,

1 Dziękuję Recenzentom tego artykułu za cenne uwagi i poprawki. Tekst powstał w ramach projektu finansowanego przez Narodowe Centrum Nauki (2014/13/B/HS6/03741). 
pozwolę sobie przytoczyć fragment, który dla mnie - jako tłumaczki nieprofesjonalnej, lecz zawodowo zajmującej się nauką - był pewnym objawieniem. Stanisław Barańczak w Ocalonym w tłumaczeniu, pastwiąc się nad jednym z przekładów Szekspira autorstwa Macieja Słomczyńskiego, pisze: „Parę przykładów z Makbeta [...] wystarczy za ilustrację okrucieństwa, z jakim polski jedenastozgłoskowiec $(5+6)$ traktuje tłumaczy nie potrafiących sobie poradzić z jego pułapkami” (2007: 271-272). Jak można by te słowa przenieść na grunt tłumaczeń naukowych? Z czym musi potrafić sobie radzić tłumacz tekstu naukowego, także wszak obfitującego w pułapki? Co ma tu wyznaczać kanon pracy tłumacza? Pomijam problemy urody językowej tłumaczeń, stylistycznej zręczności, adekwatnego oddania stylu oryginału, co do których znaczenia w tłumaczeniu naukowym spierają się specjaliści, a które bezskutecznie usiłuja przekonująco zoperacjonalizować translatolodzy. Chodzi mi o rzecz o wiele bardziej fundamentalna: niełatwo jest określić oczekiwania wobec dobrego tłumaczenia tekstu naukowego, poza tym, że znajomość dyscypliny, do której należy oryginał, powinna jakoś wpływać na jakość przekładu. W nauce jednak - inaczej niż w literaturze - smak nie jest wystarczającym kryterium.

Tu dochodzimy do trzeciego źródła wątpliwości związanych z tłumaczeniami jako pracami naukowymi, na którym chciałabym skupić się w tym tekście. Znajomość dyscypliny jest bowiem między innymi znajomością poprzednich tłumaczeń. Wędrówki pojęć w nauce odbywały się - i wciąż się odbywaja - za pośrednictwem przekładów, dokonywanych na pograniczu różnych języków potocznych oraz powstałych na ich podstawie specjalistycznych języków naukowych. Posiadanie własnego naukowego języka było i jest dla wielu narodów przedmiotem ambicji. Ma ono dowodzić twórczych zdolności władającej określonym językiem społeczności, a zarazem jej przynależności do wielkiej rodziny naukowo płodnej - a zatem cywilizowanej i nowoczesnej - ludzkości. Zakorzenienie języka nauki w języku potocznym prowadzi zresztą niekiedy do zabawnych trudności translatorskich, nie tylko w humanistyce i naukach społecznych: pomyślmy choćby o niemieckim słowie Säure (kwas), jego związku ze słowem Sauerstoff (tlen), a następnie o wbijanym nam w szkole do głowy doniosłym podziale kwasów na tlenowe i beztlenowe ${ }^{2}$.

Zabawy w etymologie i tropienie komicznych paradoksów (a także ich niekiedy całkiem poważnych konsekwencji) to znakomita wprawka dla historyków nauki. Współczesny przyrodoznawca, zadumawszy się nad słowami w rodzaju niemieckiego Sauerstoff czy rosyjskiego kislorod, wzruszy

${ }^{2}$ Przykład ten zawdzięczam dr. Janowi Surmanowi. 
prawdopodobnie ramionami nad nieefektywnością starego nazewnictwa, a następnie stwierdzi, że w dzisiejszym świecie problemy tego rodzaju będa zanikać, ponieważ tłumaczenia (w tym i tworzenie neologizmów terminologicznych) stają się zbędne $\mathrm{w}$ miarę upowszechniania się znajomości języków międzynarodowych. Nauk społecznych i humanistyki dotyczy to zapewne w mniejszym stopniu. Fakty dokonane, do których w naszych czasach należy przede wszystkim umacniana instytucjonalnie hegemonia angielszczyzny, również i w tych obszarach podważaja jednak potrzebę namysłu nad oryginalnością tłumaczeń i standardami ich oceny. Pod znakiem zapytania staje bowiem zasadność tłumaczenia jako taka: po co tłumaczyć, skoro i tak wszyscy musimy znać angielski, przynajmniej w takim zakresie, w jakim jest to niezbędne do uprawiania własnej dyscypliny?

To ostatnie zastrzeżenie otwiera zupełnie nowa puszkę Pandory. Fikcja, zgodnie z którą wszyscy znamy angielski wystarczająco jak na nasze potrzeby, opiera się bowiem na kilku kontrfaktycznych przesłankach. Maja one bezpośredni związek nie tyle ze stanem pluralizmu językowego w nauce, ile - by się tak górnolotnie wyrazić - z pewnym ideałem przekładu naukowego i wyrosłej na jego gruncie ideologii. By ją zrekonstruować, zacznę od przyczyn, dla których tłumaczenia naukowe - przy wszystkich wątpliwościach co do ich statusu - wciąż istnieja i, co więcej, wciąż są tworzone przez naukowców, często o wysokim statusie zawodowym. Następnie przejdę - inspirując się pojęciem „nie-czytania” Pierre’a Bayarda (zob. Bayard 2008) - do ideału przekładu naukowego i niektórych problemów z jego realizacją. Ostatnim punktem będzie diagnoza ideologii, w którą wrodził się ideał, i jej niepokojących praktycznych konsekwencji, które obserwuję od wielu lat jako czytelniczka i nie-czytelniczka, autorka, tłumaczka, recenzentka, redaktorka i - co w tym kontekście być może najważniejsze - wykładowczyni.

\section{/// Po co (wciąż) tłumaczyć?}

Pewne motywacje, którymi w przeszłości kierowali się tłumacze tekstów naukowych, zdecydowanie straciły dziś na znaczeniu, w każdym razie w Polsce. Najważniejsza z nich była bowiem - jak zwykle zakładamy chęć umożliwienia czytelnikom zapoznania się z treścią tekstu we własnym języku, co inaczej byłoby dla nich trudne lub niemoźliwe z powodu nieznajomości języka, niedostępności tekstu oryginalnego lub trudności w jego lekturze. Założenie to pozwala nam między innymi traktować daty pojawienia się tłumaczeń rozmaitych utworów na różne języki jako mier- 
nik przekonania tłumacza (redaktora, wydawcy, recenzenta wydawniczego, wreszcie społeczności czytelników) o potrzebie i wadze lektury tych utworów przez społeczności posługujące się tymi językami (zob. np. Sułek 2011: 17). Jeśli wydawca, tłumacz lub redaktor jest ważną postacią w społeczności naukowej albo wydawnictwo cieszy się renomą, mamy powód przypuszczać, że przekonanie to jest uzasadnione. Jeśli w dodatku tłumaczenie powoduje wzrost liczby nawiązań, interpretacji, cytowań i zastosowań dydaktycznych, przypuszczenie przeradza się w pewność.

Dziś stosowanie powyższego wnioskowania nieuchronnie prowadziłoby na manowce niemal w każdej kulturze akademickiej. Wyjątkiem byłaby hegemoniczna nauka amerykańska, gdzie faktycznie książka niewydana po angielsku zdaje się w zasadzie nie istnieć ani w nauczaniu, ani w nauce, jak tego dowodzi przebieg recepcji prac Michaiła Bachtina czy Axela Honnetha. Dostępność tekstów rośnie w naszych czasach stale (nawet jeśli ich ceny są zaporowe), wiele cennych prac wydaje się w wolnym dostępie, dodruki powstają łatwo dzięki nowym technologiom, biblioteki digitalizują i wprowadzają swoje zbiory do internetu. Teksty powstałe po angielsku czyta większość naukowców, przynajmniej w Europie, a wiele dzieł napisanych w innych językach dociera do szerszej publiczności w angielskich przekładach. Choć więc trudno odpowiedzialnie orzec, czy poziom znajomości języków obcych innych niż angielski w populacji naukowców rośnie, czy spada, samo upowszechnienie się angielskiego gwarantuje intensyfikację obiegu literatury obcojęzycznej.

Ponadto, trudność języka oryginału nie jest dziś - jak mi się zdaje traktowana jako istotny czynnik wpływający na trudność lektury, a przecież są wśród socjologów (nawet współczesnych) autorzy, którzy wcale nie pisza łatwo, i to nie z powodu skomplikowanej terminologii, lecz ze względu na bogactwo słownictwa i złożoność składni, jak choćby Peter Baehr (zob. Baehr 2008) lub Donald N. Levine (zob. Levine 2015). Nie sądzę, by przyczyną było jakieś powszechne uproszczenie się języka nauki, zubożenie leksyki czy banalizacja frazeologii - choć zapewne zjawiska takie występuja. Socjologia pozostaje zawsze, wedle wyrażenia Roberta A. Nisbeta, formą sztuki (zob. Nisbet 2002), ale formą hybrydowa. Jak to ujął Piotr Sztompka:

Mamy zatem pewną skalę rozciagającą się między dwoma biegunami: z nauką na jednym biegunie, a sztuką na drugim. Na tej skali blisko sztuki lokuje się humanistyka, a blisko nauki niektóre z tzw. 
nauk behawioralnych [...]. Socjologia znajduje się gdzieś pomiędzy, w środku skali. Niektóre jej subdyscypliny czy teorie troszkę bliżej sztuki, np. socjologia fenomenologiczna czy socjologia historyczna, a inne nieco bliżej nauki, np. socjologia matematyczna czy mikrosocjologia. Ale zawsze socjologia jest pewną hybrydą: trochę nauką, a trochę sztuka (Sztompka 2011: 44).

Język jest nie jedynym wprawdzie, ale głównym tworzywem tej hybrydowej sztuki. To, że zmienia się on i różnicuje, jest zdrowym objawem: sztuka trzymająca się uparcie jednego kanonu byłaby martwa. To zrozumiałe, że wzbogacenie repertuaru środków twórczych o inny język pociaga za sobą zmianę kanonu - podobne zjawiska obserwowano w literaturze wielokrotnie, zwłaszcza w Europie, na styku języków narodowych i łaciny, w okresie kształtowania się zalążków literatur narodowych. Proces, który zachodzi dziś w nauce, nie jest więc bezprecedensowy. Rzecz w tym, że rosnącemu naciskowi na nabywanie znajomości języków obcych towarzyszy dziś fikcyjne założenie, że jest to właściwość zero-jedynkowa, nie zaś stopniowalna. Nikt w końcu nie weryfikuje tego, w jakim stopniu uczony zrozumiał pracę, którą cytuje. Okazję do tego typu sprawdzianów kompetencji językowych studentów dają zajęcia obcojęzyczne i translatoria. Nikt systematycznie nie sprawdza biernej znajomości języka obcego pośród uczonych, trudno bowiem uznać konferencje międzynarodowe za dobra okazję do tego typu testów.

Jeśli pominiemy przesłanki podejmowania się tłumaczenia związane $z$ dazżeniem do przybliżenia tekstu rodzimemu czytelnikowi, pozostają inne. Nie najbłahszą z nich jest potrzeba estetyczna. Niektóre teksty, nawet naukowe, zachęcają do podjęcia wyzwania, jakim jest tłumaczenie. Wiąże się z tym intelektualna potrzeba zmierzenia się z trudnościami, jakich nastręcza przekład myśli autora na inny język, i poddania tym samym sprawdzianowi własnej znajomości języka docelowego. Zagadki i ich rozwiązywanie, począwszy od dziwactw autora, poprzez brakujące lub mylące przypisy, błędy rzeczowe i językowe, poetyzację języka, aluzje i zapożyczenia, neologizmy terminologiczne, aż po realia kulturowe, do których autor się odnosi - to nieodłączna część pracy tłumacza.

Tłumaczenie, redagowanie i wydawanie tłumaczeń może też wynikać we względów praktycznych, niekoniecznie zarobkowych. Często wiążą się one z dydaktyka. Studenci kierunków innych niz filologiczne - bynajmniej nie tylko w Polsce - wbrew powszechnym życzeniom rzadko znaja jakikol- 
wiek język obcy na tyle, by bez pomocy nauczyciela czytać w nim tekst naukowy (opieram ten sąd wyłącznie na własnym doświadczeniu). Niektóre zespoły badawcze tłumaczą teksty na użytek wewnętrzny dla ujednolicenia terminologii. Bywa też, że tłumaczenie wynika z potrzeby uzupełnienia tak czy inaczej zdefiniowanej luki wydawniczej (jedyna nietłumaczona praca danego autora, ważny, a dotąd pomijany tekst), wyprzedzenia wydawniczej konkurencji, łatwiejszego zdobycia - dzięki jednemu tłumaczeniu - praw do innych prac tego samego autora, itp.

Oczywiście, nie można także pominąć ideowej motywacji tłumaczy i wydawców tekstów naukowych. Standardową miarą prestiżu nauki określonej granicami państwowymi jest na przykład dysponowanie korpusem klasycznych tekstów we własnej wersji językowej. Możliwość operowania własnym językiem jest często uznawana za warunek oryginalności i twórczości teoretycznej. Opisywanie badanych społeczeństw w ich własnych językach wydaje się - zwłaszcza w badaniach jakościowych - elementarnym wymogiem metodologicznym. Ściągnięcie innych na własny grunt w celu uzyskania porozumienia z nimi podnosi status nie tylko w rokowaniach międzynarodowych, lecz także w nauce.

Wreszcie, zachodzi także filozoficzna potrzeba tłumaczenia. Nauka nie zaczęła się wczoraj, powstała w określnych językach i rozwijała się poprzez obieg pojęć i ich przenikanie do innych języków. Gdyby nikt nigdy niczego nie tłumaczył, to nie powstałyby być może dyscypliny z krajowym idiolektem naukowym, który dziś tak wiele komplikuje w naszej pracy a wystarczy pomyśleć o niemieckich słowach w rodzaju Geist, a następnie wyobrazić sobie, jakie męki przeżywają ich tłumacze na japoński (zob. Schwentker 1998, 2014). Nie byłoby też kontaktu między tym, co istniało kiedy indziej i gdzie indziej, a tym, co jest teraz i tutaj. Tłumaczenie to włączanie teraźniejszości, która napływa z innych języków, w to, co się już osadziło w języku lokalnym - i na odwrót. Ta potrzeba, wolno sądzić, nigdy nie zniknie.

\section{/// Ideał przekładu naukowego}

Wszystkie powyższe potrzeby, zarówno te palące, jak i mniej pilne, mógłby zaspokoić przekład idealny. Ponieważ jednak przekładów idealnych nie ma, zamiast tego wytworzył się z czasem pewien ideał przekładu naukowego, który - choć jest to konstrukcja absolutnie nie do utrzymania z punktu widzenia logiki - stał się podstawą naszego myślenia i działania w wielu obszarach nauki. Oto przesłanki, na których opiera się ów twór: 
1. Teksty naukowe są w pełni przekładalne.

Wbrew znanej tezie Willarda Van Ormana Quine'a naukowcy często zdają się mniemać, że gdy przeczytali tłumaczenie, to przeczytali tekst równoważny w pełni oryginałowi w tym sensie, że zawierający wszystkie jego treści. Mówiąc: „Przeczytałam Zasady metody socjologicznej”, chcę więc wyrazić myśl, że przeczytałam polski przekład dzieła Émile’a Durkheima i jego treść uważam za równoważnik treści tekstu oryginalnego, mogę zatem uczciwie twierdzić, iż przeczytałam dzieło Durkheima.

2. Terminy naukowe są nieprzekładalne.

Wprawdzie teksty sa przekładalne, ale zawarte w nich terminy (a czasem i zwykłe słowa, mylnie brane za terminy teoretyczne) nie poddaja się niestety tłumaczeniu, trzeba je więc w przekładzie pozostawić w oryginale, względnie podać w nawiasach oryginalny termin. Ma to zapewne ułatwić czytelnikowi życie, tyle tylko że zakłada u czytelnika znajomość języka oryginału nie gorszą niż u tłumacza - jednak wobec tego po co miałby on czytać przekład?3. Przekład staje się grą między tłumaczem a czytelnikiem, w której obaj oddają mecz walkowerem.

3. Teksty naukowe można rozumieć i tłumaczyć pars pro toto.

Teksty naukowe są często długie, za długie jak na potrzeby czytelnika. Dlatego też bardzo często dokonujemy na nich operacji, którą w odniesieniu do tekstów artystycznych uważa się za dopuszczalną jedynie w czytankach szkolnych: wybiera się fragment (uznawany za najbardziej przydatny do założonych celów) i ten fragment się tłumaczy. Inaczej jednak niż w szkolnych wypisach - gdzie próbka tekstu ma albo być materiałem do ćwiczeń, albo zapoznawać ucznia ze specyfiką stylu, tematyki lub epoki we fragmencie dostatecznie ewidentną - wybrane fragmenty tekstów naukowych mają też przekazać w pigułce wiedzę zawartą w całym tekście. Ileż to razy zdarza się nam powoływać na to, co głosili święty Tomasz, Dante Alighieri lub Immanuel Kant w tym czy innym dziele, wyłącznie na podstawie fragmentów z antologii? Fragment, reprezentujący całość, miałby nie tracić sensu przez wyjęcie go z kontekstu całości.

4. Teksty naukowe pozostaja ze sobą w takich relacjach, jak znane nam ich treści.

\footnotetext{
${ }^{3}$ Oczywiście, nie mam tu na myśli sytuacji, gdy trzeba po prostu pójść za ustalonym uzusem lub ułatwić czytelnikowi ustalenie, do jakiego terminu odnosi się polski odpowiednik proponowany przez tłumacza, zwłaszcza w wypadku terminów lepiej znanych w języku oryginału (np. Geisteswissenschaften, Wertrationalität) lub takich, których po prostu często zdarzało się dotąd nie przekładać (np. bandwagon effect). Ponadto, zdarzają się faktycznie terminy nieprzekładalne albo mylące w przekładzie, nawet jeśli na pozór proste: moim ulubionym jest francuskie słowo populaire stosowane w wielu kontekstach socjologicznych.
} 
Przewaga treści nad formą i kontekstem sprawia, że teksty naukowe w głowach czytelników przekładów układają się w konfiguracje, którymi rządzi porządek treści, nie zaś jakikolwiek inny (historyczny, stylistyczny, personalny, geograficzny, językowy, kulturowy). Takie uprzywilejowanie treści prowadzi oczywiście często do zabawnych ahistoryzmów (zdarzyło się raz, że na warsztatach dla licealistów, którzy mieli przed spotkaniem zapoznać się z kilkoma wyposażonymi w niewiele datowników esejami Georga Simmla, spytano mnie, czy autor jeszcze żyje). Dla socjologa naturalnym porządkiem organizującym teksty będzie oczywiście porządek empirii (temat, przedmiot, obszar badań), teorii i metody. Ten porządek będzie następnie naturalizowany i podnoszony do statusu faktycznego, nie zaś narzuconego ładu.

\section{/// Nie-czytanie przekładu, czyli czego? O kłopotach z ideałem}

Bayard ukuł niegdyś pojęcie nie-čytania (zob. Bayard 2008), by zobrazować zjawisko bardzo podobne do tego, z jakim mamy do czynienia w naukowym obiegu tłumaczonych tekstów. Bayard opisał nie-czytanie, odwołując się do postaci bibliotekarza z Cz̨owieka bez wtaśsiwości Roberta Musila. Otóż najbardziej charakterystyczną cechą bibliotekarza było to, że nigdy nie przeczytał żadnej z powierzonych mu książek. Wyrzekł się on czytania nie dlatego, że nie chciał swoich książek znać, lecz przeciwnie - po to, by znać je lepiej, bo czytanie zawęża horyzonty: „Kto zajmie się treścią, ten już jest zgubiony jako bibliotekarz [...], bowiem nigdy już nie zdoła wyrobić sobie poglądu na całość" (Musil 1971: 174). Czytanie tylko tytułów i spisów rzeczy pozwala utrzymać dystans wobec tekstów, zachować nad nimi kontrolę, co w wypadku bibliotekarza jest naturalnie warunkiem przetrwania. Nieodżałowanej pamięci Terry Pratchett, tworząc postać bibliotekarza-orangutana w cyklu Świat dysku, wygrał ten motyw na tysiące komicznych sposobów. Czytanie jednak gubi, a nie-czytanie ratuje nie tylko bibliotekarzy.

Nie-czytanie przybiera wiele form: kompletnej nieznajomości, kartkowania, przeglądania, znajomości ze słyszenia. Książki nie-przeczytane to także książki, które zapomnieliśmy. Nie-czytanie nie tylko nie przeszkadza, ale wręcz pomaga mówić, pisać i myśleć oraz wyrażać sądy o książkach - jest poza tym konieczne i nieuniknione, a przy tym świadczy o większym niż czytanie szacunku dla książek (Bayard 2008: 22). Bayard dowodzi: 
Mądrość postawy bibliotekarza z Człowieka bez. właściwości tkwi, moim zdaniem, właśnie w tym dążeniu do zachowania „poglądu na całość". [...] Ten, kto zbyt głęboko wsadza nos w książki, traci kontrolę nad kultura, a nawet nad lekturą. Ze względu na wielka liczbę istniejących na świecie dzieł absolutnie konieczne jest dokonanie wyboru między owym całościowym spojrzeniem a skupianiem się na konkretnych książkach. Każda lektura jest bowiem trudnym i czasochłonnym przedsięwzięciem, a zatem nieuniknioną stratą energii, której potrzebujemy, by zachować kontrolę nad całością (2008: 19).

Nie-czytanie jest korzystne, choć może zagrozić prestiżowi i dobrej (samo)ocenie, bo „dla niedoświadczonego obserwatora nic nie wydaje się bardziej podobne do nieczytania niż nie-czytanie. Trudno też o kogoś bardziej podobnego do osoby, która nie czyta, niż osoba, która nie-czyta" (Bayard 2008: 3). Nieczytanie kompromituje. Bayard namawia nas więc, byśmy je precyzyjnie i raz na zawsze odróżnili od nie-czytania i przestali się wstydzić tego ostatniego, jest ono bowiem nie tylko warunkiem orientacji w całości, ale i możliwości budowania wspólnej biblioteki, która umożliwia komunikowanie się z innymi. Ideał tłumaczenia, który przed chwilą opisałam, jest krokiem w tym słusznym kierunku, a oto dlaczego:

Po pierwsze, oryginały sa pomijalne, a przekłady łatwo je zastępują, co oszczędza czytania oryginałów, a także tłumaczeń, i ułatwia niewstydzenie się tego, że się nie wie, że jakiś tekst stanowi przekład (na przykład angielski z języka niderlandzkiego albo niemieckiego) lub że został przełożony na określony język docelowy. Na przykład: coraz częściej spotykam się dziś w Polsce, nawet w publikacjach renomowanych wydawnictw, ze zjawiskiem świadczącym o wielkiej odwadze tłumaczy, którzy cytaty z dzieł dostępnych po polsku (czasem, niestety, od tak dawna, że zapomnianych) tłumaczą osobiście raz jeszcze, nie zadając sobie trudu poszukiwania odpowiednich fragmentów w polskiej wersji. Nie przypisuję tym tłumaczom lenistwa czy nieumiejętności przeszukiwania internetu, a co najmniej niektórzy z nich świadomi sa zapewne tego, że obyczaje w pracy translatorskiej były do niedawna inne. Nie wątpię też, że w wielu wypadkach decyzje tego rodzaju powodowane sa po prostu niską oceną istniejącego przekładu lub trudnościami z dotarciem do niego, nieproporcjonalnymi do wagi sprawy. Myślę jednak, że bardzo często zdarza się tłumaczom sądzić, że ich przekład jednego zdania cytowanego z Davida Hume’a czy Petera Sloterdijka 
będzie ekwiwalentem treściowym tegoż zdania w całej przełożonej przez kogoś książce, po co więc do wysiłku, jaki już zadał sobie tłumacz całości, dokładać jeszcze własny trud jej kartkowania w poszukiwaniu właściwego cytatu. Nie-czytanie oryginałów idzie tu w parze z nie-czytaniem tłumaczeń, zysk na czasie jest więc podwójny.

Podobnie ma się sprawa $z$ terminami: tłumacz często nawet nie stara się dowiedzieć, jaki jest uzus terminologiczny, i tłumaczy po swojemu, dodając $\mathrm{w}$ nawiasie - zgodnie $\mathrm{z}$ drugim punktem ideału tłumaczenia - termin oryginalny. Taki stan rzeczy jest typowy dla obszarów badań, które jeszcze nie wypracowały uzusu albo w których jest on słabo zakorzeniony, jak dziś w Polsce badania nad pamięcią, a jeszcze niedawno ilościowe badania społeczne ${ }^{4}$. Często jednak uzus bywa lekceważony i nie sposób nawet dociec, dlaczego. Wyjaśnienia dostarcza ideał tłumaczenia. Skoro bowiem terminy są i tak nieprzekładalne, to jeden nie-przekład terminu jest równie dobry jak drugi, a przecież samo zadawnienie w języku nie może stanowić o przewadze któregokolwiek z nich. Pojawia się kusząca myśl, że wszystkie składniki stuprocentowo przetłumaczalnej całości są nieprzekładalne, być może więc całość powinna być wzięta w nawias?

W ten sposób przechodzimy do trzeciego nie-czytelniczego waloru ideału. Wspólna biblioteka powstaje jako zasób komunikacyjny i komunikowanie się jest głównym celem jej twórców: trzeci punkt ideału przekładu to praktyczna realizacja postulatów Bayarda. Nie-czytanie całości, z których pochodzą fragmenty tłumaczone i czytane, nie jest problemem, ponieważ tylko te fragmenty wchodzą do zasobu komunikacyjnego i staja się źródłem wydajnych komunikacyjnie, bo uwspólnionych przez edukację i nie-lekturę skojarzeń. Dlatego też antologie tak są oporne na zmiany dostępności tekstów oryginalnych. Na przykład Sžkice z socjologii religii Maxa Webera mają się świetnie, choć przesłanki ich użyteczności w postaci niedostępności pełnych wydań tekstów dawno się zdezaktualizowały. Powstają także nowe antologie przekładów wybranych fragmentów, tak z tekstów klasycznych, jak i najzupełniej współczesnych ${ }^{5}$, i założę się, że będą one w użyciu na zajęciach dydaktycznych długo po publikacji pełnych przekładów wszystkich tekstów źródłowych. Antologie pojawiają się szybciej, są tańsze, łatwiej dostępne, dydaktycznie i bibliotekarsko sensowniejsze, a ponadto ogromnie ułatwiają nie-czytanie. Jedno nie-czytanie (redaktora)

\footnotetext{
${ }^{4}$ Bardzo dziękuję Recenzentowi za tę uwagę.

5 Tytułem przykładu można wymienić Współczesne teorie socjologiçne. Antologia tekstów (Borowik, Mucha 2015), Nowe perspektywy teorii socjologicznej. Wybór tekstów (Manterys, Mucha 2009), Świat çłowieka - swiat kultury. Antologia tekstów klasycznej antropologii (Nowicka, Głowacka-Grajper 2007), Klasyczne teorie socjologiçne. Wybór tekstów (Śpiewak 2006).
} 
skutkuje kolejnym nie-czytaniem (tłumacza, który może wszak nie znać całości), to zaś prowadzi do nie-czytania czytelnika końcowego. Współpracowałam przy tego rodzaju przedsięwzięciach jako tłumaczka, redaktorka, współautorka wyboru, korektorka i redaktorka językowa, korzystam z wyborów jako nauczycielka i dostrzegam ich wielkie zalety, z których największą jest właśnie to, że oduczają szkodliwego zażenowania wywołanego nie-czytaniem.

Czwarty punkt ideału ma zapewne najbardziej bezpośredni związek z nie-czytaniem, ponieważ na gruncie pomysłu Bayarda trudno rozdzielić książkę i opinię o niej. To, że teksty układają nam się w takie same konfiguracje, jak ich znane nam z nie-czytania treści, jest więc nie tylko naturalne, lecz i pożądane, bo w ten sposób istnieje względnie duża szansa, że ułożą się nam wszystkim jednakowo albo przynajmniej podobnie. Dzięki temu wspólna biblioteka będzie działać bez zarzutu: na jej półkach stać będa opatrzone tytułami całości części, które będą wywoływać u każdego z nas wystarczająco podobne skojarzenia dzięki eliminacji nadmiaru mogącego generować różnice: nasze opinie wydawane będą na podstawie tej samej synekdochy.

\section{/// Fałszywe całości, czyli ideologia lektury}

Ideał nie-czytania i ideał tłumaczenia wzmacniają się więc wzajemnie i wywierają istotny wpływ nie tylko na naszą naukowa praktykę, lecz także na nasze o niej wyobrażenie. Niestety, praktyka owa i wyobrażenie o niej rozmijają się w kilku istotnych punktach, przez co dochodzi do ideologizacji naszego myślenia o nas samych jako czytelnikach przekładów, a w szerszej perspektywie - także do ideologizacji naszych badań, gdy postanowimy zająć się krążeniem pojęć, idei i tekstów.

Spójrzmy najpierw na ten pierwszy aspekt. Praktyka prowadzi do coraz dalej idącej fragmentaryzacji dzieł, oderwania treści fragmentów od całości, a treści całości od jakiegokolwiek jej nośnika, rozluźnienia relacji między tekstem oryginalnym a opinią o tekście oryginalnym powziętą na podstawie przekładu. Dodatkową konsekwencją funkcjonowania ideału tłumaczenia naukowego jest tworzenie się w różnych obiegach językowych odrębnych konfiguracji skojarzeń treściowych, które są wzajem nieprzekładalne, powstają bowiem w wyniku różnie zakrojonych fragmentaryzacji. Moim zdaniem jest to większy problem niż nieuchronne różnice terminologiczne wynikające $z$ tłumaczeń, $z$ najbardziej być może znaczącym dla współczesnego życia społecznego i kulturalnego 
przykładem Freudowskich terminów $i d$, ego i superego na czele (zob. Bettelheim 1991).

Krążenie pojęć naukowych, dokonujące się za pomocą słów używanych przez tłumaczy, polega nie tylko na zmianie słownych kostiumów, które pojęcia te noszą, lecz także na zmianie - by się tak wyrazić - całej mise en scène, w której pojęcie występuje (zob. Bal 2012). Bruno Bettelheim, który pokazał, jak amerykańskie tłumaczenia prac Sigmunda Freuda zmieniły charakter jego teorii $z$ humanistycznej w technologiczna, otwierając tym samym drogę do inżynierii jaźni w stylu zupełnie niefreudowskim, przeanalizował w istocie właśnie tego rodzaju proces: krążenia pojęć, które poprzez przekład fundamentalnie zmieniły swoją konfigurację treści. Ta sytuacja dobrze ilustruje również działanie ideału przekładu: rzekomo nieprzekładalne postanowiono oddać przez inne nieprzekładalne, tym razem łacińskie, w przekonaniu, że nie zaszkodzi to przecież całemu tekstowi. W efekcie zapoczątkowana została nowa konfiguracja treści, w której trudno rozpoznać w wędrujących pojęciach ich poprzednie wcielenia.

To samo w sobie nie byłoby jeszcze problemem, ponieważ fałszywa świadomość czytelnika przekładu nie grozi mu zwykle niczym gorszym niż blamaż w snobistycznym towarzystwie. O ile konfiguracje treści są odtwarzane poprawnie i komunikacja przebiega w sposób niezakłócony, dla użytkownika nie ma większego znaczenia, skąd i jaką droga pojęcia przywędrowały (choć, jak przekonuje Mieke Bal na przykładzie pojęcia pojęcia, ma to znaczenie dla samych pojęć i dla efektów, jakie przynosi ich zastosowanie w komunikacji - zob. Bal 2012). Perspektywa zmienia się jednak diametralnie, gdy zamiast zwykłym użytkownikiem, jesteśmy badaczem użytku czynionego z tekstów, pojęć i treści, na przykład jako historyk nauki.

Podam tylko jeden z przejawów omawianej ideologizacji w tej dziedzinie. Otóż jednym z najważniejszych pojęć w historii socjologii, którą zajmuję się zawodowo, jest „recepcja”. Można by uznać ją za praideę krążenia czy wędrówki pojęć, nieograniczającą się do samych pojęć, lecz obejmującą również teorie, teksty, osoby czy relacje między osobami. Recepcja dotyczy - najkrócej mówiąc - przemieszczania się idei powstałych w jednym miejscu do innego miejsca, taką czy inną droga, której wyśledzenie jest typowym zadaniem historyka. Jeśli idea wyrażona w jednym języku pojawia się następnie w innym języku, recepcja zyskuje dodatkowy wymiar w postaci przekładu. Najczęściej badania recepcji (niezależnie od tego, czy myślimy o niej w kategoriach ogólnych, czy też koncentrujemy się na jednym autorze lub wręcz jednym dziele albo jednej idei) sprowadzają się do badania losów 
tekstów traktowanych jako nośniki idei. Wśród tekstów wyróżniona pozycję mają teksty pisane o charakterze jednoznacznie naukowym. Wykłady, rozmowy, prywatne listy $\mathrm{i}$ inne podobne formy przekazu idei zwracaja na siebie mniejszą uwagę badaczy recepcji w historii nauki, choć zdarzają się naturalnie wyjątki (zob. np. Czarnowski 2015). Kluczowe są książki (rzadziej krótsze teksty): daty ich tłumaczeń (lub nietłumaczeń - zob. Bucholc 2013), daty ich publikacji w oprawie twardej i miękkiej, liczba odwołań do nich, wznowienia, ponowne tłumaczenia i nowe redakcje, pojawienie się ich tytułów na listach lektur i w bibliografiach itd.

$\mathrm{Na}$ czym polega problem $z$ tak rozumianym badaniem recepcji? Przede wszystkim na tym, że abstrahuje ono od wpływu ideału tłumaczenia, zakładając odpowiedniość tekstu w punkcie wyjścia i dojścia. Metaforycznie rzecz ujmując, sądzimy, że pojęcie przebiera się w inną szatę słowną, ale pozostaje tym samym, a jeśli nawet nie, to można prześledzić dokładnie i wyjaśnić przyczynowo modyfikacje, jakim uległo, często traktując je w kategoriach błędu lub przeinaczenia (zob. Baehr 2001). Wiara w istnienie pojęcia oryginalnego wraz z przekonaniem o jego zasadniczej nieprzekładalności (czyli swoistości i jedyności związku między nim a jego treścia) skutkuje więc, paradoksalnie, uznaniem za równorzędne wszystkich tekstów pochodnych, w których pojęcie to jest przekładane. Tymczasem pojęcia ulegają transformacji i zmieniaja się wraz ze zmianą konfiguracji, złożonej z nowych fragmentów, bo tak działa ideał tłumaczenia, i nie zachodzi między nimi relacja pierwotności innej niż - ewentualnie - chronologiczna, ta zaś w wyjaśnianiu komunikacyjnej pracy pojęć bywa mało przydatna.

Ponadto, ruch pojęć w tłumaczeniach odbywa się nie w jedną, lecz w dwie strony, choć niekiedy ruch zwrotny bywa trudny do dostrzeżenia lub niezbyt intensywny. Recepcja rzadko bywa całkowicie bierna, choć jest to naturalnie wyobrażalne. Znakomitym przykładem zmiany, jakiej ulegaja pierwotne pojęcia po przekładzie, umożliwiającym im wędrówkę w obszar innego języka, jest los pojęcia figuracji w socjologii Norberta Eliasa. Niemiecki termin Figuration Elias zaczerpną w latach 30. XX wieku najprawdopodobniej od Friedricha Nietzschego (Mongardini 1996: 295). Używał go zawsze w sensie zbliżonym do polskiego „konfiguracja” lub „układ”, na określenie wzajemnego układu jednostek powiązanych relacjami współzależności (Merz-Benz 1996: 47). Nie traktował go jednak jako terminu technicznego, nie definiowal i odwoływał się bardziej do skojarzeń potocznych lub etymologicznych aniżeli do jakiejkolwiek teoretycznej projekcji (więcej na ten temat zob. Bucholc 2013: 19). Po przetłumaczeniu na angielski Figuration stało się figuration. To słowo istnieje także w angielskim 
i ma kilka znaczeń odnoszących się do nadawania całości określonej formy poprzez ustanawianie relacji między jej elementami. W wersji angielskiej termin Eliasa zrobił karierę. Stał się częścią wyrażeń takich jak figurational approach i figurational paradigm, a w innych językach, na przykład w polskim, konsekwentnie „socjologia figuracyjna”. Takie rozszerzenie i formalizacja znaczenia pierwotnego terminu spotykało się ze sprzeciwem samego Eliasa, zupełnie bezskutecznie, co dowodzi, że pojęcia nie podlegają bynajmniej wykładni autentycznej swoich twórców, nawet jeśli ci ostatni maja jeszcze szansę za życia obserwować ich wędrówki. Dla nas najważniejsze jest jednak, że wskutek anglicyzacji pojęcia Figuration również w niemieckim obiegu językowym zaczęło ono nabierać sensu technicznego, który w moim odczuciu - wypacza sens humanistycznej i historycznej socjologii Eliasowskiej, podobnie jak było to w wypadku pojęć Freuda.

\section{/// Za co warto zapłacić?}

Przykład Freudowskiego ego i Eliasowskiej „figuracji” dobrze pokazuje ideologiczny charakter pojęcia recepcji. Nic nie bywa przejmowane jeden do jednego i niczego nie da się przejąć, nie ponosząc przy tym kosztów, czasem bardzo wysokich. Badacz recepcji, który nie dostrzega zaburzeń jednokładności pojęć wędrujących i intelektualnych (a także estetycznych) kosztów translacji, ulega złudzeniu optycznemu.

Rodzi się jednak pytanie o zasadność ponoszenia tych kosztów. Należy ją rozpatrywać w związku z motywami, dla których wciąż tłumaczymy teksty naukowe $z$ obcych języków, traktując to jako jeden $z$ warunków recepcji obcej twórczości naukowej, a recepcję uznając za zjawisko pożądane, zwłaszcza gdy recypowane treści cieszą się wysokim prestiżem w innych obszarach językowych. Płacimy za to, by pojęcia wędrowały, ponieważ dążymy do budowania wspólnej z innymi biblioteki, przekraczającej granice języków, umożliwiającej ponadgraniczną komunikację, wzajemne zrozumienie i współpracę. Nie-czytanie rzeczy dotąd nieczytanych, które ma nam umożliwiać recepcja, można odideologizować względnie łatwo, uświadamiając sobie, że właśnie nie-czytanie jest warunkiem recypowania tego, co cudze. Gdyby było nam to dostępne w pełni, byłoby nasze.

Pojęcie nie-czytania każe nam wyobrażać sobie poszczególne doświadczenia (i czytelnicze, i nie-czytelnicze) jako nieregularne wielokąty indywidualnych opinii nakładające się na siebie maleńką częścią wspólną. Ta część wspólna to opinio communis, podstawa wspólnej biblioteki, która nie musi pozostawać w żadnej relacji do będącego jej przedmiotem dzieła 
(rys. 1). Ideał natomiast zakładałby, że wielokąty opinii indywidualnych są foremne, jednokładne, a część wspólna jest równokształtna im i dziełu zarazem (rys. 2).

Taka sytuacja to oczywiście ideologiczna mrzonka: tłumacz nie jest agentem czytania, lecz nie-czytania, ale ani czytanie, ani nie-czytanie nie dawałoby nigdy tego rodzaju jednokładności.

Pojęcie nie-czytania pomaga jednak również zrozumieć, dlaczego ideał tłumaczenia, którego konsekwencją jest ideologizacja naszych praktyk i naszego samorozumienia, musi przynosić takie właśnie, a nie inne skutki - i dlaczego musi istnieć. Posiadanie wspólnej biblioteki jest imperatywem, jednak takim samym imperatywem jest, byśmy nie pamiętali, na jak kruchych opiera się ona podstawach i jak niewielką część opinii indywidualnych możemy uznać za wspólną. Komunikacja, w nauce jak i gdziekolwiek indziej, musi polegać na fikcji porozumienia - ideał tłumaczenia zapewnia pożywkę tej fikcji.

Rys. 1.

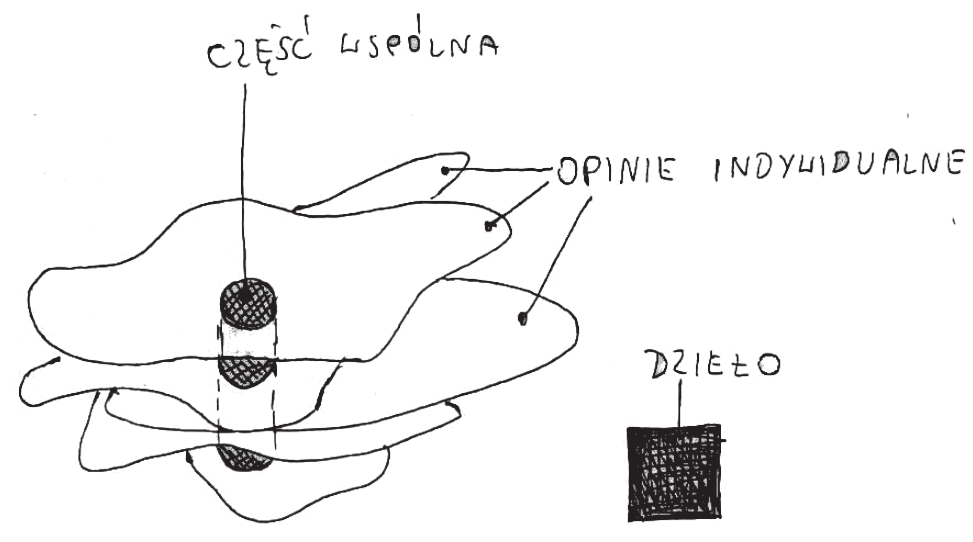

Rys. 2.

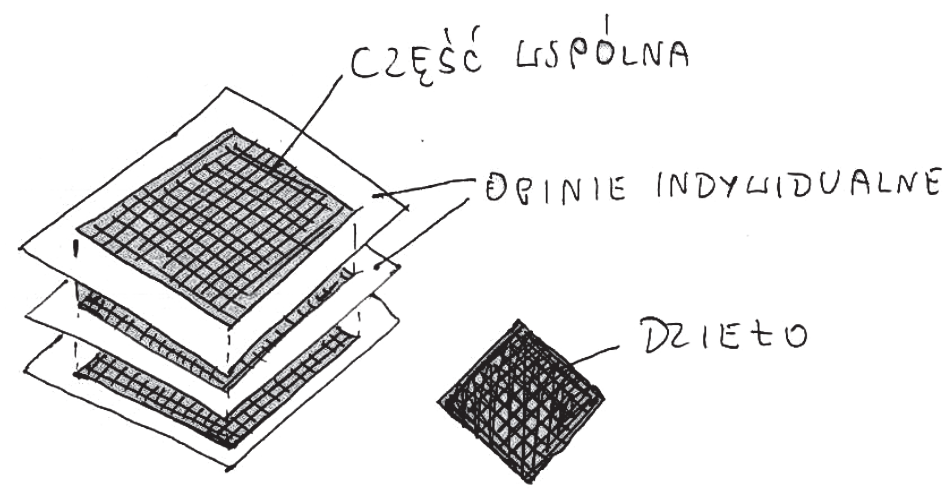


Bibliografia:

/// Baehr P. 2001. The "Iron Cage” and the "Shell as Hard as Steel”. Parsons, Weber, and the Stablhartes Gebäuse Metaphor in the Protestant Ethic and the Spirit of Capitalism, „History and Theory”, nr 40(2), s. 153-169.

/// Baehr P. 2008. Caesarism, Charisma and Fate. Historical Sources and Modern Resonances in the Work of Max Weber, Transaction Publishers.

/// Bal M. 2012. Wedrujace pojecia w naukach humanistycznych. Krótki przewodnik, tłum. M. Bucholc, Narodowe Centrum Kultury.

/// Barańczak S. 2007. Ocalone w ttumaczeniu. Szkice o warsztacie ttumacza poezji z dodatkiem małej antologii przeleładón-problemów, Wydawnictwo a5.

/// Bayard P. 2008. Jak rozmawiać o ksiażkach, których sie nie crytało?, tłum. M. Kowalska, Państwowy Instytut Wydawniczy.

/// Bettelheim B. 1991. Frend i dusza lud₹ka, tłum. D. Danek, Państwowy Instytut Wydawniczy.

/// Borowik I., Mucha J., red. 2015. Wspótczesne teorie socjologiczne. Antologia tekstów, Zakład Wydawniczy „Nomos”.

/// Bucholc M. 2013. Samotność dtugodystansowca. Na obrz̨eżach socjologii Norberta Eliasa, Wydawnictwo Naukowe PWN.

/// Czarnowski S. 2015. Listy do Henri Huberta i Marcela Maussa (1905-1937), red. K. Kończal, J. Wawrzyniak, tłum. F. Rogalski, D. Thiriet, Instytut Socjologii UW, Oficyna Naukowa.

/// Levine D.N. 2015. Social Theory as a Vocation. Genres of Theory Work in Sociology, Transaction Publishers.

/// Manterys A., Mucha J., red. 2009. Nowe perspektywy teorii socjologicznej. Wybór tekstów, Zakład Wydawniczy „Nomos”.

/// Merz-Benz P.U. 1996. Verstrickt in Geschichte. Norbert Elias in seiner Breslauer Zeit, [w:] Norbert Elias und die Menschenwissenschaften. Studien zur Entstebung und Wirkungsgeschichte seines Werkes, red. K.-S. Rehberg, Suhrkamp, s. 40-57.

/// Mongardini C. 1996. „Ist die Gesellschaft möglich?”- Georg Simmel, Norbert Elias und die Aufgaben einer soziologischen Neuorientierung, [w:] Norbert Elias und die Menschenwissenschaften. Studien zur Entstehung und Wirkungsgeschichte seines Werkes, red. K.-S. Rehberg, Suhrkamp, s. 291-302. 
/// Musil R. 1971. Człowiek bę właściwości, t. 2, tłum. K. Radziwiłł, K. Truchanowski, J. Zeltzer, Państwowy Instytut Wydawniczy.

/// Nisbet R.A. 2002. Sociology as an Art Form, Transaction Publishers.

/// Nowicka E., Głowacka-Grajper M., red. 2007. Świat çłowieka - swiat kultury. Antologia tekstón klasycznej antropologii, Wydawnictwo Naukowe PWN.

/// Schwentker W. 1998. Max Weber in Japan. Eine Untersuchung zur Wirkungsgeschichte 1905-1995, Mohr Siebeck.

/// Schwentker W. 2014. Japanische Kontroversen über Max Webers Protestantische Ethik, [w:] Max Weber in der Welt. Rezeption und Wirkung, red. M. Kaiser, H. Rosenbach, Mohr Siebeck.

/// Sułek A. 2011. Le suicide $w$ Polsce. Studium wędrómki i recepcji klasyki socjologicznej, [w:] tegoż, Obrazy z życia socjologii w Polsce, Oficyna Naukowa, s. $17-54$.

/// Sztompka P. 2011. Czy istnieje socjologia polska?, „Studia Socjologiczne”, nr 201(2), s. 43-54.

/// Śpiewak P., red. 2006. Klasyczne teorie socjologicænne. Wybór tekstów, Wydawnictwo Naukowe PWN.

\section{/// Abstrakt}

Tekst stanowi omówienie problemów związanych z tworzeniem i obiegiem tłumaczeń tekstów z zakresu nauk społecznych we współczesnym świecie. Posługując się pojęciem „nie-czytania” Pierre’a Bayarda, autorka rekonstruuje ideał przekładu naukowego, analizuje ideologiczne skutki kierowania się nim w pracy translatorskiej i jego wpływ na tworzenie wiedzy socjologicznej, zwłaszcza zaś na pracę dydaktyczna.

Słowa kluczowe:

tłumaczenie, czytanie, nie-czytanie, socjologia akademicka

\section{/// Abstract}

This article is about problems related to translations in the social sciences and their circulation in the contemporary world. Drawing on Pierre Bayard's concept of "non-reading", the author reconstructs the ideal of 
scientific translation and analyses the ideological consequences of the orientation it produces in translators' work and its impact on the creation of sociological knowledge and on the academic teaching of sociology in particular.

Key words:

translation, reading, non-reading, academic sociology 